\title{
A Rolling Circle Amplification Screen for Polyomaviruses Other than BKPyV in Renal Transplant Recipients Confirms High Prevalence of Urinary JCPyV Shedding
}

\author{
Jeanette Kluba ${ }^{a} \quad$ Silvia Linnenweber-Held ${ }^{b} \quad$ Albert Heim $^{a} \quad$ Angella M. Ang $^{a}$ \\ Lubna Ragguba Verena Broecker ${ }^{c}$ Jan U. Becker ${ }^{c}$ Thomas F. Schulza \\ Anke Schwarz ${ }^{b}$ Tina Ganzenmueller ${ }^{a}$

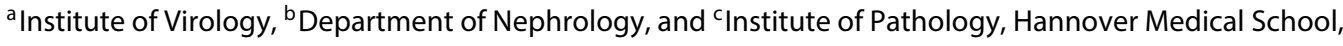 \\ Hannover, Germany
}

\section{Key Words}

Human polyomavirus (HPyV) - JC polyomavirus (JCPyV) -

Kidney transplantation - Urinary shedding - Rolling circle amplification

\begin{abstract}
Objectives: Multiple novel human polyomaviruses (HPyVs) have been discovered in the last few years. These or other, unknown, nephrotropic HPyVs may potentially be shed in urine. Methods: To search for known and unknown HPyVs we investigated BKPyV-negative urine samples from 105 renal transplant recipients (RTR) by rolling circle amplification (RCA) analysis and quantitative JCPyV PCR. Clinical data was analysed to identify risk factors for urinary polyomavirus shedding. Results: In 10\% (11/105) of the urine samples RCA with subsequent sequencing revealed JCPyV, but no other HPyV sequences. Using quantitative JCPyV PCR, 24\% (25/105) of the samples tested positive. Overall sensitivities of RCA of $44 \%(11 / 25)$ in detecting JCPyV in JCPyV DNA-positive urine and $67 \%(10 / 15)$ for samples with JCPyV loads $>10,000$ copies $/ \mathrm{ml}$ can be assumed. Despite frequent detectable urinary shedding of JCPyV in our cohort, this could not be correlated with clinical risk factors. Conclusion: Routine urinary JCPyV monitoring in BKPyV-negative RTR without suspected poly-
\end{abstract}

omavirus-associated nephropathy might be of limited diagnostic value. As RCA works in a sequence-independent manner, detection of novel and known polyomaviruses shed in sufficient quantities is feasible. High-level shedding of HPyVs other than BKPyV or JCPyV in the urine of RTR is unlikely to occur.

(c) 2015 S. Karger AG, Basel

\section{Introduction}

Polyomaviruses are small non-enveloped viruses with circular double-stranded DNA genomes approximately $5 \mathrm{~kb}$ in length [1]. Besides the well-characterized human polyomaviruses (HPyVs) BK virus (BKPyV) and JC virus (JCPyV), numerous 'novel' HPyVs have been discovered in recent years [reviewed by 2, 3]: the Merkel cell polyomavirus (MCPyV) [4], WUPyV [5], KIPyV [6], TSPyV [7], HPyV-6, -7 [8], -9 [9], -10 [10] (MWPyV [11]/MXPyV [12]), -12 [13], STLPyV [14] and NJPyV [15].

Many studies have investigated the role of BKPyV [16] in causing polyomavirus-associated nephropathy

J.K. and S.L.-H. contributed equally to this work.

\section{KARGER 125}

(c) 2015 S. Karger AG, Base

$0300-5526 / 15 / 0582-0088 \$ 39.50 / 0$

E-Mail karger@karger.com

www.karger.com/int
Tina Ganzenmueller

Institut für Virologie, Medizinische Hochschule Hannover

Carl-Neuberg-Strasse 1

DE-30625 Hannover (Germany)

E-Mail Ganzenmueller.Tina@ @mh-hannover.de 
(PVAN) in renal transplant recipients (RTR) [17]. Its diagnosis is based on the detection of polyomavirus in the transplant biopsy, e.g. via immunohistochemistry and also by quantitative PCR monitoring of the BKPyV load in urine and peripheral blood. Very high BKPyV urine loads and detection of high BKPyV DNAemia levels (i.e. $>10,000$ copies $/ \mathrm{ml}$ ) are indicators of a $\mathrm{BKPyV}$-associated nephropathy [18-21]. JCPyV, the causative agent of progressive multifocal leukoencephalopathy $[22,23]$, is also frequently shed in the urine of both RTR and immunocompetent individuals, but only a few cases of PVAN have been attributed to JCPyV [24-27].

HPyVs are mainly transmitted during childhood - or might be of donor origin in RTR [28] - and establish persistent infections that can reactivate upon immunosuppression of the host [29]. Seroprevalence data show the presence of antibodies against a broad range of $\mathrm{HPyV}$ in healthy adults/blood donors (BKPyV 82\%, JCPyV 3951\%, KIPyV 55-67\%, WUPyV 69-89\%, MCPyV 25-69\%, HPyV-6 69\%, HPyV-7 35\% and HPyV-9 47\%, TSPyV up to $70 \%)$ and organ transplant recipients (BKPyV up to 97\%, JCPyV up to 80\% and HPyV-9 41-63\%) [8, 30-35].

Due to the increasing spectrum of recently identified polyomaviruses and their ability to establish persistent infections one might expect shedding of additional, potentially unknown HPyVs in the urine, in particular in immunocompromised patients. In the past, novel HPyVs such as TSPyV, HPyV6 and HPyV7 and also animal polyomaviruses have been successfully identified using the rolling circle amplification (RCA) technique $[7,8,36-$ 38 ], which employs a phi29 polymerase to amplify circular DNA in a sequence-independent manner [39].

The aim of this study was to identify known or unknown nephrotropic polyomaviruses in urine from 105 $\mathrm{BKPyV}$-negative RTR using an RCA screen. In addition, we analysed clinical data and histopathological findings from renal biopsies to identify potential risk factors for polyomaviruria.

\section{Materials and Methds}

\section{Patients, Specimens and Study Design}

One hundred and five RTR (median age 51 years, range 18-72 years, $68 \%$ male; table 1), who underwent monitoring for BKPyVassociated nephropathy at the outpatient clinic of the Department of Nephrology, Hannover Medical School, between 02/2010 and $12 / 2011$ participated in this study. Patients' written informed consent was obtained and the study was approved by the local ethics committee of Hannover Medical School (No. 1425-2012). Patients were included if they had undergone kidney transplantation in the previous 14 months and if the current urine sample obtained for
Table 1. Patient characteristics and virological findings of the 105 RTR (renal transplant recipients)

Patients, $\mathrm{n}$ 105

Gender male, $\mathrm{n}(\%)$

Median age at transplantation, years (range)

$51(18-72)$

Immunosuppressive regimen, $\mathrm{n}(\%)$

Corticosteroids

$105(100)$

Antimetabolites

CNI

m-TOR inhibitors

Median time of urine sampling after transplantation, days (range)

Positive JCPyV PCR from urine, $\mathrm{n}(\%)$

Positive RCA result, $\mathrm{n}(\%)$

$11 / 105(10)$

Positive anti-SV40 immunohistochemistry ${ }^{\mathrm{a}}$, n (\%)

$1 / 88(1)$

routine diagnostic $\mathrm{BKPyV}$ load monitoring produced a negative result following BKPyV PCR (Real-Star BKPyV PCR Kit, Altona $\mathrm{GmbH}$; limit of detection $3.6 \times 10^{2}$ copies $/ \mathrm{ml}$ ).

The urine samples were obtained at a median of day 180 (range 6-387) after kidney transplantation and were tested using RCA and quantitative JCPyV PCR. In addition, JCPyV PCR was performed on peripheral EDTA blood samples (also obtained for routine BKPyV monitoring on the same day as the urine samples) for all patients who were found to be positive following JCPyV PCR from urine. Clinical data such as renal function or immunosuppressive regimen and - if available - histopathological biopsy results (acute rejection or presence of PVAN) were extracted from medical records to identify factors potentially associated with urinary $\mathrm{HPyV}$ shedding. Renal function was assessed using serum creatinine levels (range of normal values: $59-104 \mu \mathrm{mol} / \mathrm{l}$ for male and $45-84 \mu \mathrm{mol} / \mathrm{l}$ for female patients, respectively) and the estimated glomerular filtration rate (eGFR, calculated according to the Chronic Kidney Disease Epidemiology Collaboration group [40, 41]; normal value $>90 \mathrm{ml} / \mathrm{min} / 1.73 \mathrm{~m}^{2}$ ).

\section{Histopathology}

Histopathology results from renal biopsies (protocol or indication biopsies according to the Hannover protocol biopsy programme [42]) were available for $88 / 105$ patients. Biopsies were taken on the same day $(n=82)$ or within 6 weeks before or after $(n=6)$ the tested urine sample was obtained. All transplant renal biopsies were diagnosed by a nephropathologist (J.U.B., V.B.) according to the Banff classification [43] and routinely analysed for the presence of polyomavirus using Anti-SV-40 immunohistochemical (IHC) staining. A distinct tubular epithelial nuclear staining was regarded as positive and qualified for a diagnosis of PVAN.

\section{DNA Isolation and PCR}

Total DNA from $200 \mu$ lof urine or EDTA whole blood was isolated using the QIAamp Blood Mini Kit (Qiagen) according to the manufacturer's recommendations and eluted in a volume of $50 \mu$ l. Samples were stored at $4^{\circ}$ for a maximum of $24 \mathrm{~h}$ until DNA extraction; extracted nucleic acids were stored at $-20^{\circ}$. Quantitative realtime JCPyV PCR (JCV Q-PCR Alert Kit, Nanogen Advanced Diag- 
nostics S.r.L.; limit of detection $2.5 \times 10^{2}$ copies $/ \mathrm{ml}$; linear quantification between $2.5 \times 10^{2}$ and $2.5 \times 10^{7}$ copies $/ \mathrm{ml}$ ) was performed on $20 \mu \mathrm{l}$ of the extracted DNA on an ABI 7500 (Applied Biosystems).

RCA, Restriction Analysis, Cloning and Sequencing

Rolling circle amplification (RCA) was performed using the REPLI-g Kit (Qiagen) as recommended by the manufacturer using $5 \mu \mathrm{l}$ of isolated DNA; $5 \mu \mathrm{l}$ of the resulting RCA product was digested with 10 units of restriction enzyme and screened via gel electrophoresis. Following in silico restriction analysis of polyomavirus reference strains we chose the enzymes XbaI, BamHI or EcoRI, which were likely to cut all currently known human polyomavirus reference genomes once (JCPyV, BKPyV, STLPyV, MWPyV, MCPyV, WUPyV, KIPyV, TSPPyV, NJPyV) or twice (HpYV-6, -7, -9 and -12), and thus were likely to lead to distinct restriction patterns upon gel electrophoresis. In addition, the restriction assays using these enzymes would also recognize 33 out of 36 animal reference polyomavirus genomes (23/33 with a single cutting site, 10/33 with two cutting sites).

If a fragment pattern corresponding to the size of a linearised polyomavirus genome was observed, the rest of the RCA reaction was digested with 60 units of the appropriate restriction enzyme, fragments were extracted and cloned into the pBluescript KS II + vector. The constructs were sequenced using M13 primers (forward GTA AAACGACGGCCAGT, reverse GGAAACAGCTATGACCATG) on an ABI 3130 sequencer (Applied Biosystems) and sequences analysed using BLAST to screen the nucleotide collection database.

\section{Statistics}

Statistical analysis was performed using SPSS version 19.0 (SPSS Inc.); p values $<0.05$ were considered significant in two-sided tests. Group comparisons were performed using Pearson's $\chi^{2}$ or Fisher's exact test where appropriate for categorical variables, e.g. presence of rejection, gender, changes in the eGFR or qualitative test results. The Mann-Whitney $U$ test was applied to determine differences between groups relating to quantitative parameters, such as age, serum creatinine or viral load. For JCPyV load values above or below the limit of linear quantification by the JCPyV PCR, statistical calculations were performed using the respective limits as surrogate values, i.e. $2.5 \times 10^{2}$ copies $/ \mathrm{ml}$ for values below the PCR limit of linear quantification and $2.5 \times 10^{7}$ copies $/ \mathrm{ml}$ for values above the limit of linear quantification. To statistically calculate changes of the graft function we divided patients into three subgroups upon follow-up: decrease in the eGFR of $10 \%$ or more, eGFR changes of less than $10 \%$, and increase in the eGFR of $10 \%$ or more than compared to the initial eGFR, respectively.

\section{Results}

\section{Detection of the HPy Vs by RCA}

Using the RCA screening assay with restriction enzyme analysis and subsequent Sanger sequencing 11/105 (10.4\%) urine samples tested positive for JCPyV (table 1). In 6 other samples cloning and sequencing of fragments revealed sequences derived from either human DNA $(\mathrm{n}=$ $1)$ or TT viruses $(n=5)$. No other polyomaviruses except JCPyV were detected.

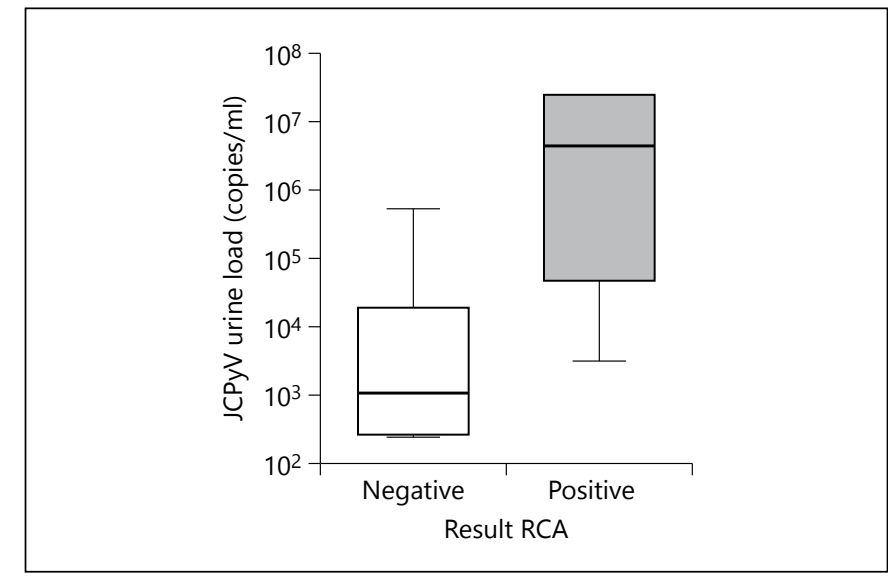

Fig. 1. JCPyV loads in urine samples that tested negative or positive by RCA. JCPyV DNA was detectable by RCA in 11 out of 25 urine samples that tested positive by quantitative JCPyV PCR. The box plot shows that RCA-positive urine samples had a significantly higher median JCPyV load $\left(4.4 \times 10^{6}\right.$ copies $/ \mathrm{ml}$; Mann-Whitney $\mathrm{U}$ test: $\mathrm{p}<0.001$ ) than samples tested negative by RCA (median $1.1 \times 10^{3}$ copies $\left./ \mathrm{ml}\right)$.

\section{JCPyV Real-Time PCR in Urine or Peripheral Blood}

In total 25 out of 105 (23.8\%) urine samples were positive upon quantitative JCPyV PCR (table 1; median viral load $1.2 \times 10^{4}$ copies $\left./ \mathrm{ml}\right) ; 4$ samples were below the limit of linear quantification $\left(2.5 \times 10^{2}\right.$ copies $\left./ \mathrm{ml}\right)$ and 5 above the limit of linear quantification $\left(2.5 \times 10^{7}\right.$ copies $\left./ \mathrm{ml}\right)$. For all patients with JCPyV DNA-positive urine samples, peripheral blood was screened for JCPyV DNA using quantitative PCR on EDTA blood samples obtained on the same day as the urine samples. Only 3 out of the 25 blood samples were faintly JCPyV DNA-positive $\left(<2.5 \times 10^{2}\right.$ copies $/ \mathrm{ml}$ ). JCPyV loads from the urine of the respective patients were relatively high $\left(4.4 \times 10^{6}\right.$ copies $/ \mathrm{ml}$ in 1 case and $>2.5 \times 10^{7}$ copies $/ \mathrm{ml}$ in the 2 other patients). The median urinary JCPyV load of these patients was statistically significantly higher compared to the urinary JCPyV load of patients without JCPyV DNAemia $(p=0.023)$.

\section{Sensitivity of the RCA Determined by Quantitative JCPyV Real-Time PCR}

All 11 urine samples which were positive upon RCA also tested positive by quantitative JCPyV PCR. The RCA-positive samples had a significantly $(\mathrm{p}<0.001)$ higher median urinary JCPyV load $\left(4.4 \times 10^{6}\right.$ copies/ $\mathrm{ml}$, range $3.8 \times 10^{3}$ to $\left.>2.5 \times 10^{7}\right)$ than $\mathrm{RCA}$-negative samples, which had a median of $1.1 \times 10^{3}$ (range $<2.5 \times$ $10^{2}$ to $5.3 \times 10^{5}$ ) copies/ml (fig. 1 ). RCA yielded a positive result in only 1 out of 10 samples with JCPyV
90

Intervirology 2015;58:88-94 DOI: $10.1159 / 000369210$
Kluba et al. 
Table 2. Comparison of clinical results from patients with and without positive JCPyV DNA detection in urine

\begin{tabular}{|c|c|c|}
\hline Gender male, $\mathrm{n}(\%)$ & $56 / 80(70)$ & $15 / 25(60)$ \\
\hline Median age at transplantation, years (range) & $52(18-71)$ & $43(18-72)$ \\
\hline \multicolumn{3}{|l|}{ Immunosuppressive regimen, $\mathrm{n}(\%)$} \\
\hline Corticosteroids, CNI and antimetabolite & $73 / 80(91)$ & $21 / 25(84)$ \\
\hline Corticosteroids plus antimetabolite or CNI & $3 / 80(4)$ & $3 / 25(12)$ \\
\hline Mean serum creatinine levels on day of urine sampling, $\mu \mathrm{mol} / \mathrm{l}$ (range) & $158(79-419)$ & $160(96-287)$ \\
\hline Mean eGFR on day of urine sampling, $\mathrm{ml} / \mathrm{min} / 1.73 \mathrm{~m}^{2}$ (range) & $45.9(13.9-91.3)$ & $45.5(19.5-86.7)$ \\
\hline Mean serum creatinine levels on day of follow-up, $\mu \mathrm{mol} / \mathrm{l}$ (range) ${ }^{\mathrm{a}}$ & $153(84-386)$ & $148(91-269)$ \\
\hline Mean eGFR on day of follow-up, $\mathrm{ml} / \mathrm{min} / 1.73 \mathrm{~m}^{2}{\text { (range })^{\mathrm{a}}}$ & $49.5(13.9-99.0)$ & $50.4(18.5-85.0)$ \\
\hline \multicolumn{3}{|l|}{ Changes in eGFR upon follow-up, $\mathrm{n}(\%)^{\mathrm{a}}$} \\
\hline Decrease of $10 \%$ or more & $19 / 77(25)$ & $3 / 25(12)$ \\
\hline Banff IA and B & $2 / 68(3)$ & $1 / 20(5)$ \\
\hline Banff IIA and B & $3 / 68(4)$ & $2 / 20(10)$ \\
\hline
\end{tabular}

None of the presented parameters showed statistically significant differences between patients with and without urinary JCPyV shedding. ${ }^{a}$ Data available for 102 patients. ${ }^{b}$ Data available for 88 patients.

loads $\leq 1.0 \times 10^{4}$ copies $/ \mathrm{ml}$, but in 10 out of the $15 \mathrm{sam}$ ples with JCPyV loads $>1.0 \times 10^{4}$ copies $/ \mathrm{ml}$. As the RCA method works in a sequence-independent manner these results for JCPyV can be used to roughly calculate the sensitivity of RCA for the detection of polyomaviruses in general: using our protocol a sensitivity of the RCA assay of 44\% (11 out of 25) for HPyV DNApositive urine samples in general and of $66.6 \%$ (10 out of 15) for samples with HPyV loads $>10,000$ copies $/ \mathrm{ml}$ can be assumed.

\section{Histopathology Results}

For 88 patients renal biopsy results were available, one of which showed positive nuclear polyomavirus staining but without associated interstitial inflammation or tubulitis (day 180 after transplantation). This patient also tested positive for JCPyV by RCA and had a high JCPyV load upon quantitative PCR $\left(>2.5 \times 10^{7}\right.$ copies $/ \mathrm{ml}$ ) from a urine sample obtained on the same day as the biopsy. However, in a follow-up biopsy (day 305 after transplantation) the polyomavirus immunochemistry was negative and did not confirm the diagnosis of JCPyV-associated nephropathy. Four EDTA blood samples obtained between day 46 and day 305 after transplantation tested negative for JCPyV DNA al- though the corresponding urine samples contained more than $2.5 \times 10^{7} \mathrm{JCPyV}$ genome copies $/ \mathrm{ml}$.

Twenty-one (23.9\%) out of 88 patients for whom a renal biopsy was available showed signs of acute rejection (borderline $\mathrm{n}=13$; Banff IA + IB $\mathrm{n}=3$; Banff IIA + IIB $n=5)$. Five out of these 21 patients had positive JCPyV PCR results from urine (table 2; range of JCPyV loads $<2.5 \times 10^{2}$ to $>2.5 \times 10^{7}$ copies $/ \mathrm{ml}$ ) and 1 patient simultaneously had a low positive JCPyV PCR result from blood.

\section{Clinical Data}

On the day of urine sampling the patients' mean serum creatinine level was $158 \mu \mathrm{mol} / \mathrm{l}$ (range 79-419) and the mean eGFR was $45.7 \mathrm{ml} / \mathrm{min} / 1.73 \mathrm{~m}^{2}$ (range 13.9-91.3). For 102/105 patients follow-up data for serum creatinine levels (mean 152, range $84-386 \mu \mathrm{mol} / \mathrm{l}$ ) and the eGFR (mean 49.1, range $13.9-99.0 \mathrm{ml} / \mathrm{min} / 1.73 \mathrm{~m}^{2}$ ) were available at a median of day 466 (range 75-917) after the initial measurement. Upon follow-up, 22 out of the 102 patients showed a decrease in eGFR of $10 \%$ or more, 32 patients of less than 10\%, and 48 patients an increase in eGFR of more than $10 \%$ compared to the initial eGFR. Ninetyfour of $105(89.5 \%)$ patients received a combination of corticosteroids, a calcineurin inhibitor (CNI; cyclosporine or tacrolimus) and an antimetabolite (mycopheno- 
late mofetil or azathioprine) as an immunosuppressive treatment. Six (5.7\%) other patients received corticosteroids plus an antimetabolite or CNI and 5 patients (4.8\%) received corticosteroids plus an antimetabolite or $\mathrm{CNI}$ and additionally an $\mathrm{m}$-TOR inhibitor (sirolimus or everolimus).

No statistically significant differences were detected between patients with or without JCPyV shedding in the urine with respect to gender, age, presence of acute rejection, kind of immunosuppressive regimen, serum creatinine or eGFR levels on the day of urine sampling/upon follow-up or changes in the eGFR upon follow-up (table 2). Analogously, the patient subgroup $(\mathrm{n}=25)$ tested for JCPyV in peripheral blood showed no significant differences between patients with and without JCPyV DNAemia with respect to the parameters described above (data not shown).

\section{Discussion}

BKPyV-negative urine samples from 105 RTR were screened for nephrotropic HPyVs other than BKPyV using RCA and quantitative JCPyV PCR. With the exception of JCPyV we did not find any known or unknown HPyVs in the samples using the RCA method. These results are consistent with data from others, who either could not detect HPyV-6, -7, -9, KIPyV, WUPyV, TSPyV or MWPyV in urine samples using real-time PCR $[44,45]$ or reported detection only rarely and at very low concentrations ( $\mathrm{HPyV}-9, \mathrm{KIPyV}$ and WUPyV) $[3,9,46,47]$.

Nevertheless, the detection of JCPyV genomes by RCA in two thirds of urine samples with JCPyV loads $>1.0 \times$ $10^{4}$ copies/ $\mathrm{ml}$ in our study indicated a sufficient sensitivity of the RCA to identify HPyVs that are shed at significant concentrations into the urine. Due to the sequenceindependent nature of the RCA technique a similar sensitivity to that for JCPyV can be assumed for other polyomaviruses. According to our in silico restriction analysis we expect that our protocol will be able to detect the majority of known polyomaviruses (the currently known $13 \mathrm{HPyVs}$ as well as a large variety of animal polyomaviruses). In addition, sequencing of RCA products revealed TT virus sequences in some cases. TT viruses are known to be shed in various body fluids and have a circular genome that is preferentially amplified by the phi29 polymerase of the RCA assay [48-50]. Thus, we presume that the detection of potential novel, unknown HPyVs is also feasible using the RCA method. As a potential limita- tion of this study, the preselection of $\mathrm{BKPyV}$-negative urine samples might have influenced the likelihood of finding novel HPyVs in the urine: BKPyV-negative patients might have a better graft function and less immunosuppression, thus, they might be less prone to polyomavirus shedding.

Our cohort showed a prevalence of $24 \%$ for JCPyV DNA in the urine. This is within the range of urinary JCPyV shedding prevalence (3-49\%) reported for RTR $[24,51-54]$. Only one of our patients with detectable JCPyV from the urine was initially suspected to have $\mathrm{JCPyV}$-associated nephropathy due to a positive immunohistochemical staining in one of his renal biopsies, but he did not develop full-blown PVAN and all follow-up diagnostics remained negative. Neither acute graft rejection nor particular immunosuppressive treatment regimens were related to urinary JCPyV shedding in our cohort. Similarly, others reported that the immunosuppressive regimen does not affect the development of urinary JCPyV shedding and even found a lower acute graft rejection rate in patients with urinary JCPyV shedding versus patients without $[55,56]$. In another study a lower mean creatinine clearance in solid organ recipients with urinary JCPyV shedding compared to BKPyV or no HPyV shedders was observed [57]. In contrast, we did not find significant differences in graft function with respect to serum creatinine levels or eGFR between patients with or without urinary JCPyV shedding. These findings, together with the high prevalence of urinary JCPyV shedding, could indicate that routine monitoring of JCPyV in the urine of BKPyV-negative RTR without suspected PVAN might be of limited diagnostic value. However, data relating to the clinical significance of JCPyV replication in RTR are scarce, and thus more intensive, prospective studies are necessary.

In conclusion, although we did not discover novel HPyVs in this cohort of $105 \mathrm{BKV}$-negative RTR, the RCA technique was successfully used for the sequence-independent amplification and identification of polyomaviruses in the urine. A high prevalence of known or unknown HPyVs other than BKPyV and JCPyV shed in clinically relevant concentrations (e.g. $>1.0 \times 10^{4}$ copies/ $\mathrm{ml}$ ) in the urine is therefore unlikely.

\section{Acknowledgement}

The authors would like to thank K.-H. Heiringhoff for assistance with the data bank search, S. Huebner for excellent technical assistance and P. Kay-Fedorov for critical reading of the manuscript.
Kluba et al. 


\section{References}

1 Johne R, Buck CB, Allander T, Atwood WJ, Garcea RL, Imperiale MJ, Major EO, Ramqvist T, Norkin LC: Taxonomical developments in the family Polyomaviridae. Arch Virol 2011; 156:1627-1634.

-2 Feltkamp MC, Kazem S, van der Meijden E, Lauber C, Gorbalenya AE: From Stockholm to Malawi: recent developments in studying human polyomaviruses. J Gen Virol 2012;94: 482-496.

3 Ehlers B, Wieland U: The novel human polyomaviruses HPyV6, 7, 9 and beyond. APMIS 2013;121:783-795.

4 Feng H, Shuda M, Chang Y, Moore PS: Clonal integration of a polyomavirus in human Merkel cell carcinoma. Science 2008;319: 1096-1100.

5 Gaynor AM, Nissen MD, Whiley DM, Mackay IM, Lambert SB, Wu G, Brennan DC, Storch GA, Sloots TP, Wang D: Identification of a novel polyomavirus from patients with acute respiratory tract infections. PLoS Pathog 2007;3:e64.

-6 Allander T, Andreasson K, Gupta S, Bjerkner A, Bogdanovic G, Persson MA, Dalianis T, Ramqvist T, Andersson B: Identification of a third human polyomavirus. J Virol 2007;81: 4130-4136.

7 van der Meijden E, Janssens RW, Lauber C, Bouwes Bavinck JN, Gorbalenya AE, Feltkamp MC: Discovery of a new human polyomavirus associated with trichodysplasia spinulosa in an immunocompromized patient. PLoS Pathog 2010;6:e1001024.

>8 Schowalter RM, Pastrana DV, Pumphrey KA, Moyer AL, Buck CB: Merkel cell polyomavirus and two previously unknown polyomaviruses are chronically shed from human skin. Cell Host Microbe 2010;7:509-515.

-9 Scuda N, Hofmann J, Calvignac-Spencer S, Ruprecht K, Liman P, Kuhn J, Hengel H, Ehlers B: A novel human polyomavirus closely related to the African green monkey-derived lymphotropic polyomavirus. J Virol 2011;85:4586-4590.

$\checkmark 10$ Buck CB, Phan GQ, Raiji MT, Murphy PM, McDermott DH, McBride AA: Complete genome sequence of a tenth human polyomavirus. J Virol 2012;86:10887.

-11 Siebrasse EA, Reyes A, Lim ES, Zhao G, Mkakosya RS, Manary MJ, Gordon JI, Wang D: Identification of MW polyomavirus, a novel polyomavirus in human stool. J Virol 2012; 86:10321-10326.

-12 Yu G, Greninger AL, Isa P, Phan TG, Martinez MA, de la Luz Sanchez M, Contreras JF, Santos-Preciado JI, Parsonnet J, Miller S, Derisi JL, Delwart E, Arias CF, Chiu CY: Discovery of a novel polyomavirus in acute diarrheal samples from children. PLoS One 2012;7: e49449.

$\rightarrow 13$ Korup S, Rietscher J, Calvignac-Spencer S, Trusch F, Hofmann J, Moens U, Sauer I, Voigt S, Schmuck R, Ehlers B: Identification of a novel human polyomavirus in organs of the gastrointestinal tract. PLoS One 2013;8: e58021.

14 Lim ES, Reyes A, Antonio M, Saha D, Ikumapayi UN, Adeyemi M, Stine OC, Skelton R, Brennan DC, Mkakosya RS, Manary MJ, Gordon JI, Wang D: Discovery of STL polyomavirus, a polyomavirus of ancestral recombinant origin that encodes a unique $\mathrm{T}$ antigen by alternative splicing. Virology 2013;436:295-303.

15 Mishra N, Pereira M, Rhodes RH, An P, Pipas JM, Jain K, Kapoor A, Briese T, Faust PL, Lipkin WI: Identification of a novel polyomavirus in a pancreatic transplant recipient with retinal blindness and vasculitic myopathy. J Infect Dis 2014;210:1595-1599.

16 Gardner SD, Field AM, Coleman DV, Hulme B: New human papovavirus (B.K.) isolated from urine after renal transplantation. Lancet 1971;1:1253-1257.

17 Hirsch HH, Randhawa P: BK virus in solid organ transplant recipients. Am J Transplant 2009;9(suppl 4):S136-S146.

18 Bechert CJ, Schnadig VJ, Payne DA, Dong J: Monitoring of $\mathrm{BK}$ viral load in renal allograft recipients by real-time PCR assays. Am J Clin Pathol 2010;133:242-250.

19 Drachenberg CB, Hirsch HH, Ramos E, Papadimitriou JC: Polyomavirus disease in renal transplantation: review of pathological findings and diagnostic methods. Hum Pathol 2005;36:1245-1255.

20 Brocker V, Schwarz A, Becker JU: BK virus nephropathy after kidney transplantation. Pathologe 2011;32:399-405.

21 Boudreault AA, Courtemanche C, Latulippe E, Cote I, Houde I, Deschenes L: Screening for polyomavirus associated nephropathy in renal transplantation with blood viral load measurement. J Clin Virol 2009;45:318-321.

22 Tavazzi E, White MK, Khalili K: Progressive multifocal leukoencephalopathy: clinical and molecular aspects. Rev Med Virol 2012;22: 18-32.

23 Padgett BL, Walker DL, ZuRhein GM, Eckroade RJ, Dessel BH: Cultivation of papovalike virus from human brain with progressive multifocal leucoencephalopathy. Lancet 1971;1:1257-1260.

24 Delbue S, Ferraresso M, Ghio L, Carloni C, Carluccio S, Belingheri M, Edefonti A, Ferrante P: A review on JC virus infection in kidney transplant recipients. Clin Dev Immunol 2013;2013:926391.

25 Drachenberg CB, Hirsch HH, Papadimitriou JC, Gosert R, Wali RK, Munivenkatappa R, Nogueira J, Cangro CB, Haririan A, Mendley $S$, Ramos E: Polyomavirus BK versus JC replication and nephropathy in renal transplant recipients: a prospective evaluation. Transplantation 2007;84:323-330.

-26 Kantarci G, Eren Z, Demirag A, Dogan I, Cakalagaoglu F, Yilmaz G: JC virus-associated nephropathy in a renal transplant recipient and comparative analysis of previous cases. Transpl Infect Dis 2011;13:89-92.
27 Kazory A, Ducloux D, Chalopin JM, Angonin $\mathrm{R}$, Fontaniere B, Moret $\mathrm{H}$ : The first case of JC virus allograft nephropathy. Transplantation 2003;76:1653-1655.

28 Schmitt C, Raggub L, Linnenweber-Held S, Adams O, Schwarz A, Heim A: Donor origin of BKV replication after kidney transplantation. J Clin Virol 2014;59:120-125.

29 Dalianis T, Hirsch HH: Human polyomaviruses in disease and cancer. Virology 2013; 437:63-72.

30 Neske F, Prifert C, Scheiner B, Ewald M, Schubert J, Opitz A, Weissbrich B: High prevalence of antibodies against polyomavirus WU, polyomavirus KI, and human bocavirus in German blood donors. BMC Infect Dis 2010;10:215.

31 Egli A, Infanti L, Dumoulin A, Buser A, Samaridis J, Stebler C, Gosert R, Hirsch $\mathrm{HH}$ : Prevalence of polyomavirus BK and JC infection and replication in 400 healthy blood donors. J Infect Dis 2009;199:837-846.

32 Kean JM, Rao S, Wang M, Garcea RL: Seroepidemiology of human polyomaviruses. PLoS Pathog 2009;5:e1000363.

33 Antonsson A, Pawlita M, Feltkamp MC, Bouwes Bavinck JN, Euvrard S, Harwood CA, Naldi L, Nindl I, Proby CM, Neale RE, Waterboer $\mathrm{T}$ : Longitudinal study of seroprevalence and serostability of the human polyomaviruses JCV and BKV in organ transplant recipients. J Med Virol 2013;85:327-335.

34 Trusch F, Klein M, Finsterbusch T, Kuhn J, Hofmann J, Ehlers B: Seroprevalence of human polyomavirus 9 and cross-reactivity to African green monkey-derived lymphotropic polyomavirus. J Gen Virol 2012;93:698-705.

- 35 Chen T, Mattila PS, Jartti T, Ruuskanen O, Soderlund-Venermo M, Hedman K: Seroepidemiology of the newly found trichodysplasia spinulosa-associated polyomavirus. J Infect Dis 2011;204:1523-1526.

36 Halami MY, Dorrestein GM, Couteel P, Heckel G, Muller H, Johne R: Whole-genome characterization of a novel polyomavirus detected in fatally diseased canary birds. J Gen Virol 2010;91:3016-3022.

- 37 Johne R, Wittig W, Fernandez-de-Luco D, Hofle U, Muller H: Characterization of two novel polyomaviruses of birds by using multiply primed rolling-circle amplification of their genomes. J Virol 2006;80:35233531.

-38 Stevens H, Bertelsen MF, Sijmons S, Van Ranst M, Maes P: Characterization of a novel polyomavirus isolated from a fibroma on the trunk of an African elephant (Loxodonta africana). PLoS One 2013;8:e77884

39 Johne R, Müller H, Rector A, van Ranst M, Stevens H: Rolling-circle amplification of viral DNA genomes using phi29 polymerase. Trends Microbiol 2009;17:205-211.

40 Cirillo M: Evaluation of glomerular filtration rate and of albuminuria/proteinuria. J Nephrol 2010;23:125-132. 
41 Levey AS, Stevens LA, Schmid CH, Zhang YL, Castro AF 3rd, Feldman HI, Kusek JW, Eggers P, Van Lente F, Greene T, Coresh J; CKDEPI (Chronic Kidney Disease Epidemiology Collaboration): A new equation to estimate glomerular filtration rate. Ann Intern Med 2009;150:604-612.

42 Schwarz A, Mengel M, Gwinner W, Radermacher J, Hiss M, Kreipe H, Haller H: Risk factors for chronic allograft nephropathy after renal transplantation: a protocol biopsy study. Kidney Int 2005;67:341-348.

-43 Solez K, Colvin RB, Racusen LC, Haas M, Sis B, Mengel M, Halloran PF, Baldwin W, Banfi G, Collins AB, Cosio F, David DS, Drachenberg C, Einecke G, Fogo AB, Gibson IW, Glotz D, Iskandar SS, Kraus E, Lerut E, Mannon RB, Mihatsch M, Nankivell BJ, Nickeleit V, Papadimitriou JC, Randhawa P, Regele H, Renaudin K, Roberts I, Seron D, Smith RN, Valente M: Banff 07 classification of renal allograft pathology: updates and future directions. Am J Transplant 2008;8:753-760.

-44 Bialasiewicz S, Whiley DM, Lambert SB, Nissen MD, Sloots TP: Detection of BK, JC, WU, or KI polyomaviruses in faecal, urine, blood, cerebrospinal fluid and respiratory samples. J Clin Virol 2009;45:249-254.

45 Rockett RJ, Sloots TP, Bowes S, O’Neill N, Ye S, Robson J, Whiley DM, Lambert SB, Wang D, Nissen MD, Bialasiewicz S: Detection of novel polyomaviruses, TSPyV, HPyV6, HPyV7, HPyV9 and MWPyV in feces, urine, blood, respiratory swabs and cerebrospinal fluid. PLoS One 2013;8:e62764.
6 Csoma E, Sapy T, Meszaros B, Gergely L: Novel human polyomaviruses in pregnancy: higher prevalence of BKPyV, but no WUPyV, KIPyV and HPyV9. J Clin Virol 2012;55:262265.

47 Csoma E, Meszaros B, Asztalos L, Konya J, Gergely L: Prevalence of WU and KI polyomaviruses in plasma, urine, and respiratory samples from renal transplant patients. J Med Virol 2011;83:1275-1278.

48 Okamoto H: History of discoveries and pathogenicity of TT viruses. Curr Top Microbiol Immunol 2009;331:1-20.

49 Chan PK, Chik KW, Li CK, Tang NL, Ming MS, Cheung JL, Ng KC, Yuen PM, Cheng AF: Prevalence and genotype distribution of TT virus in various specimen types from thalassaemic patients. J Viral Hepat 2001;8:304309.

50 Wolff C, Diekmann A, Boomgaarden M, Korner MM, Kleesiek K: Viremia and excretion of TT virus in immunosuppressed heart transplant recipients and in immunocompetent individuals. Transplantation 2000;69: 351-356.
51 Randhawa P, Uhrmacher J, Pasculle W, Vats A, Shapiro R, Eghtsead B, Weck K: A comparative study of BK and JC virus infections in organ transplant recipients. J Med Virol 2005;77:238-243.

52 Pires EP, Bernardino-Vallinoto CV, Alves DM, Migone SR, Machado LF, Ishak MO, Ishak R, Cayres-Vallinoto IM, Vallinoto AC: Prevalence of infection by JC and BK polyomaviruses in kidney transplant recipients and patients with chronic renal disease. Transpl Infect Dis 2011;13:633-637.

53 Yin WY, Lu MC, Lee MC, Liu SC, Lin TY, Lai NS: A correlation between polyomavirus JC virus quantification and genotypes in renal transplantation. Am J Surg 2010;200:53-58.

54 Funahashi Y, Kato M, Fujita T, Takai S, Kimura Y, Gotoh M: Prevalence of polyomavirus positivity in urine after renal transplantation. Transplant Proc 2014;46:564-566.

55 Cheng XS, Bohl DL, Storch GA, Ryschkewitsch C, Gaudreault-Keener M, Major EO, Randhawa P, Hardinger KL, Brennan DC: Inhibitory interactions between $\mathrm{BK}$ and JC virus among kidney transplant recipients. J Am Soc Nephrol 2011;22:825-831.

56 Rossi AP, Anderson KL, Brennan DC: JC polyoma virus and kidney disease. Kidney Int 2014;85:1242.

57 Kusne S, Vilchez RA, Zanwar P, Quiroz J, Mazur MJ, Heilman RL, Mulligan D, Butel JS: Polyomavirus JC urinary shedding in kidney and liver transplant recipients associated with reduced creatinine clearance. J Infect Dis 2012;206:875-880. 